\title{
Legal Synchronization between Government Policy and Sharia Concepts on Lockdown Discourse during the Covid 19 Pandemic
}

\author{
Zefrizal Nurdin
}

\begin{abstract}
Legal Synchronization between Government Policy and Sharia Concepts on Lockdown Discourse during the Covid 19 Pandemic. This article aims to analyze government policies related to Large-Scale Social Restriction Policy (PSBB), known as lockdown, through the concept of Islamic law to find legal synchronization between the policy and the concept of sharia. The problem that will be answered in this study is how Islamic law regulates PSBB when an infectious disease occurs, and whether the PSBB policy has been intertwined with the provisions of the Shari'ah. This research is a normative-juridical that focuses on the problem of synchronization between the two legal systems; sharia and positive law. The results show that Shari'a provisions explicitly require that a lockdown be imposed for anyone and any interest (including collective worship activities) in an infectious area, except for medical personnel carrying out the mandate to provide health services to the community. Prohibition of going out or entering the disaster area can lead to the legal status of harâm (strongly prohibited) or makrûh (lessly prohibited) depending on the level of emergency it causes based on information from medical experts. Thus there is a legal synchronization between the provisions of the Shari'a and government policies related to the lockdown, the policies that must be adhered to by citizens for the safety of the individuals and the people as well.
\end{abstract}

Keywords: Covid-19, PSBB, synchronization of law

\begin{abstract}
Abstrak: Sinkronisasi Hukum antara Kebijakan Pemerintab dengan Konsep Syariat Terhadap Diskursus Lockdown di Masa Pandemi Covid 19. Penelitian ini bertujuan untuk menganalisis kebijakan pemerintah terkait PSBB melalui konsep syariat Islam untuk menemukan sinkronisasi hukum antara kebijakan tersebut dengan konsep syariat. Adapun permasalahan yang akan dijawab dalam penelitian ini adalah bagaimana syariat Islam mengatur PSBB ketika terjadi penyakit menular? dan apakah kebijakan PSBB tersebut telah berjalin berkelindan dengan ketentuan syariat?. Penelitian ini merupakan penelitian yuridis normatif yang bertumpu pada data sekunder, terutama berkaitan dengan problema sinkronisasi antara dua sistem hukum; syariat dengan hukum positif. Hasil penelitian menunjukkan bahwa ketentuan syariat secara tegas mengharuskan diberlakukan lockdown untuk siapapun dan kepentingan apapun (termasuk kegiatan ibadah kolektif) ketika terjadi penyakit menular pada suatu wilayah, kecuali terhadap tenaga medis yang memikul amanah untuk memberikan pelayanan kesehatan kepada masyarat. Larangan keluar atau masuk wilayah bencana dapat mengarah kepada status hukum harâm ataupun makrûh tergantung kepada tingkat kedaruratan yang ditimbulkannya berdasarkan keterangan dari para pakar medis. Dengan
\end{abstract}

Dosen di Fakultas Hukum Universitas Andalas, Padang, Kampus Limau Manis, Sumatera Barat

E-mail: zefrizalnurdin@yahoo.com 
demikian terdapat sinkronisasi hukum antara ketentuan syariat dengan kebijakan pemerintah terkait lockdown, kebijakan mana harus ditaati warga demi keselamatan individu terkait ataupun orang banyak.

Kata Kunci: Covid-19, PSBB, sinkronisasi hukum

\section{Introduction}

The increasing death toll due to the transmission of Corona Virus Disease 2019 (Covid-19) has caused anxiety in various countries throughout the world. The coronavirus has spread in almost all countries in the world and the number of infections has not shown any signs of decreasing. Until the end of March 2020, there were 720,117 cases of infection worldwide with 33,925 deaths and 149,082 recoveries. In some European countries and the United States, the death toll is even higher than in China, where the virus originated. According to the data from kompas.com as of March 30, 2020, 23 countries tried to stop the spread of the coronavirus by making lockdown rules ${ }^{1}$ Lockdown policy as the best preventive measure in overcoming transmission was supported by Khan $S$, et al who suggested that robust measures to limit the international movement of infectious individuals should be a current priority in our fight against 2019- Covid. ${ }^{2}$

In the Indonesian context, the increase in the transmission of COVID-19 prompted the Indonesian government to stipulate Government Regulation of the Republic of Indonesia Number 21 of 2020 concerning Large-Scale Social Restrictions (PSBB) in the Context of Accelerating the Handling of Covid-19, which was followed by the establishment of a national emergency related to the threat of the coronavirus through The Presidential Decree of the Republic of Indonesia number 11 of 2020 concerning the Determination of the Covid-19

${ }^{1}$ Kompas Cyber Media, 'Update 23 Negara Berlakukan Lockdown Guna Hentikan Penyebaran Virus Corona', KOMPAS.com, 2020 <https://www.kompas.com/tren/read/2020/03/30/161900865/ update-23-negara-berlakukan-lockdown-guna-hentikan-penyebaran-virus-corona> .

${ }^{2}$ S. Khan and others, 'Novel Coronavirus, Poor Quarantine, and the Risk of Pandemic', Journal of Hospital Infection, 104.4 (2020), 449-50 (pp. 1-2) <https://doi.org/10.1016/j. jhin.2020.02.002>. 
Public Health Emergency. The policy was then followed up by many regional leaders who proposed that their area be allowed to become a PSBB area.

Large-Scale Social Restrictions are part of a regional quarantine which is recently popularly known as a lockdown, an isolation that is forced to prevent contamination/transmission of disease. Thus, a person cannot go out or enter a certain area due to the above reasons. Such policies, whether applicable in broad or limited scope, will have an impact on important social activities, especially economic and educational activities. ${ }^{3}$ Apart from these 2 areas, the policy regarding the lockdown (in the form of PSBB or otherwise) turns out to also intersect with a sensitive issue, namely restrictions on the implementation of collective worship such as Friday prayers and other congregational prayers.

In the next stage, it turns out that the government's policy regarding the lockdown has received various responses from the public. The results of research on 772 respondents conducted by the FIA University of Indonesia research team found 150 respondents believed that COVID-19 was a global elite conspiracy. ${ }^{4}$ In other words, all regulations related to covid 19 are interpreted as orders from elites aimed at making profits, so they do not need to be obeyed.

Among Muslims, who quantitatively occupy the majority position in this country, this policy has also received mixed responses. The fact shows that along with the transmission of covid 19, there is also the transmission of anti-norm sentiment to most Muslims because norms are seen as part of a conspiracy by global elites who are predominantly non-Muslim to make material and immaterial profits.

${ }^{3}$ Kompas Cyber Media, 'Sejumlah Daerah Terapkan Lockdown, Ini Dampaknya Menurut Sosiolog', KOMPAS.com, 2020 <https://www.kompas.com/tren/read/2020/03/31/083000165/ sejumlah-daerah-terapkan-lockdown-ini-dampaknya-menurut-sosiolog>

${ }^{4}$ Pikiran Rakyat, 'Hasil Penelitian UI Kuak Adanya Keyakinan Warga Terkait Covid-19 Konspirasi Elite Global - Pikiran-Rakyat.com' <https://www.pikiran-rakyat.com/pendidikan/ pr-01932654/hasil-penelitian-ui-kuak-adanya-keyakinan-warga-terkait-covid-19-konspirasi-eliteglobal>. 
This pro-contra stance seems empirically real and is more dominated by anti-norm attitudes. A phenomenon found in the city of Pandang, for example, shows that on the first Friday after the appeal was issued, generally congregational Friday prayer activities in Padang City were stopped by replacing the midday prayer at their respective homes. A few days later, however, the congregation of the mosque was again active in carrying out daily worship activities collectively, especially for the 5 daily prayers. Although the local government has issued an appeal through the Mayor's instruction Number 020 of 2020 concerning PSBB, daily activities are still similar to ordinary days. The Padang City Government's appeal or request (in the text of the related letter the word requested is used instead of an order/order) to lock oneself or self-isolate by not performing collective worship outside the home, either for Friday or other 5 daily prayers to cut off the transmission line of the epidemic, turns out to be handled differently especially by the followers of Islam in this area. This fact is supported by the results of the author's research in May-July 2020 on active worshipers in 8 mosques in the city of Padang which showed that $70 \%$ of all respondents believed that covid 19 was a fabrication and conspiracy of the elite. Thus, the Padang City Government's appeal to isolate themselves by not attending mosques and prayer rooms was not obeyed and some even thought that the rules were against the teachings of the Shari'a.

The phenomenon occurred in the city of Padang, apparently also occurred in the nearest province, namely Riau Province. According to the spokesman for the Covid 19 of Riau Province, Dr. Indra Yovi, only $24 \%$ of Riau's people use masks outside their homes. This means that the socialization of PSBB has not shown satisfactory results and must be improved again so that people can be disciplined in obeying the rules that have been set. ${ }^{5}$

5 'Baru 24 Persen Warga Pakai Masker, Jubir Covid-19 Riau Ingatkan Pentingnya Disiplin Kesehatan - Riau Tanggap Virus Corona | Pemprov Riau' <https://corona.riau. go.id/2020/05/16/baru-24-persen-warga-pakai-masker-jubir-covid-19-riau-ingatkan-pentingnyadisiplin-kesehatan/>. 
Starting from the description of the public response to the government's policy regarding the lockdown/PSBB in the early days of the Covid-19 pandemic above, this study was conducted to find out how the actual provisions of Islamic law regarding lockdown in a pandemic situation are and what policies have been taken by the government in handling covid 19. is in line with the provisions of the Shari'a.

This research is normative juridical research to see whether the government's policy on PSBB is in sync with the provisions of the Shari'a, especially in the face of the Covid-19 pandemic that is sweeping the world today. The data source comes from library research/document study, including the results of empirical research reports that the author did previously through interviews and observation methods. The collected data is then processed and analyzed using certain techniques and methods commonly applied in scientific research.

\section{The Nature and Character of Islamic Shari'a}

Islamic law was revealed by Allah SWT to give guidance to mankind as a mercy for the whole world. Islamic law is general, eternal, and covers all areas of human needs. ${ }^{6}$ The main sources of Shari'a are the Qur'an and hadith which contain orders, suggestions, choices, or prohibitions aimed at mankind. Islamic law contains a set of practical teachings to behave and behave, both physical behavior, belief, mental and spiritual, as a manifestation of total and comprehensive servitude to God. Belief in the existence of a One God is part of the shari'ah which is then detailed to various aspects of human life ranging from personal problems, social relations, economics, law, and so on. ${ }^{7}$ As a consequence of faith in Allah, Islamic Sharia must be applied to all

${ }^{6}$ Iqbal Maulana and Yuni Roslaili, 'Penerapan Syariat Islam dalam Bingkai Keberagaman Nusantara', Dusturiyah: Jurnal Hukum Islam, Perundang-undangan dan Pranata Sosial, 8.2 (2019), 96-116 <https://doi.org/10.22373/dusturiyah.v8i2.4216>.

${ }^{7}$ Nurrohman Syarif, 'Syariat Islam dalam Perspektif Negara Hukum Berdasar Pancasila', Pandecta Research Law Journal, 11.2 (2016), 160-73 <https://doi.org/10.15294/pandecta. v11i2.7829>. 
lines of life, both in the context of individual, group life, as well as in the life of society and the state. ${ }^{8}$ This is what Mahmud Saltut means in his explanation that Islamic Sharia is all the rules that Allah revealed to mankind to be guided in dealing with God, fellow human beings, and with the environment. ${ }^{?}$

The main purpose of Islamic law is to protect the interests of all human beings, whether they are primary, secondary, or tertiary interests. If the balance of interests is not maintained, it will bring disaster and damage to the community itself. ${ }^{10}$ Rohadi Abdulfatah emphasized that an integralists harmonious life is the main goal of Islamic human life to achieve a stable and dynamic society. ${ }^{11}$ The task of norms (including sharia) is to maintain a balance of interests. If the orders and prohibitions are violated, it can plunge people into disaster. ${ }^{12}$

\section{About Health Quarantine}

The term lockdown (English) means to be locked out; namely locking all access in and out of an area or country. ${ }^{13}$ Law Number 6 of 2018 concerning Health Quarantine does not use the term lockdown but uses the term quarantine, either in the form of home quarantine, hospital quarantine, regional quarantine, or large-scale social restrictions.

Article 1 of Law Number 6 of 2018 states:

(1) Quarantine is the limitation of activities and/or separation of a person who is exposed to an infectious disease as stipulated in the legislation even though he has not shown any symptoms or is in the

${ }^{8}$ Nur Rohim Yunus, 'Penerapan Syariat Islam terhadap Peraturan Daerah dalam Sistem Hukum Nasional Indonesi', HUNAFA: Jurnal Studia Islamika, 12.2 (2015), 253-79 <https:// doi.org/10.24239/jsi.v12i2.394.253-279>.

9 Abd Rahim Yunus, 'Posisi Negara Dalam Penegakan Syariat Islam Dalam Perspektif Sejarah', Jurnal Adabiyah, 16.2 (2016), 114-21 <https://doi.org/10.24252/JAd.v17i116i2a2>.

${ }^{10}$ Abdul Manan, Pembaruan Hukum Islam Di Indonesia (Depok: Kencana, 2017), p. 74.

${ }^{11}$ Rohadi Abdulfatah, et al, Ilmu Dan Tehnologi Dalam Islam (Jakarta: Rineka Cipta, 1990), p. 29.

${ }^{12}$ Hasby Asshiddiqy, Al Quran Dan Terjemahnya, (Jakarta: PT. Intermasa, 1974).

${ }^{13}$ Syailendra Persada, 'Ada ODP, PDP, Dan Lockdown, Mengenal Istilah Seputar Corona', Tempo, $2020<$ https://nasional.tempo.co/read/1320573/ada-odp-pdp-dan-lockdown-mengenalistilah-seputar-corona $>$. 
incubation period, and/or the separation of containers, transportation means, or any goods suspected contaminated from people and/or goods containing disease-causing or other sources of contamination to prevent the possibility of spreading to people and/or goods in the vicinity.

(2) Home Quarantine is the limitation of occupants in a house and its contents suspected of being infected with the disease and/or contaminated in such a way as to prevent the possibility of spreading disease or contamination.

(3) Hospital Quarantine is the restriction of a person in a hospital suspected of being infected with a disease and/or contaminated in such a way as to prevent the possibility of spreading the disease or contamination.

(4) Territorial Quarantine is population restriction in an area including the entrance area and its contents suspected of being infected with a disease and/or contaminated in such a way as to prevent the possibility of spreading disease or contamination.

(5) Large-Scale Social Restrictions are restrictions on certain activities of residents in an area suspected of being infected with a disease and/or contaminated in such a way as to prevent the possibility of spreading disease or contamination.

Quarantine is more aimed at subjects suspected of being infected with a disease and/or contaminated. For subjects who are not included in the allegations, he is free to make choices to leave/enter the area affected by the infectious disease. But if the situation and conditions require, quarantine can be carried out simultaneously for both sick and healthy people. It's just that the authority to state the situation and conditions in question is not purely a regional authority but must be determined by the Minister of Health based on proposals that come from the relevant regional government. This is as regulated in Article 2 in conjunction with Article 6 of the Government Regulation of the Republic of Indonesia number 21 of 2020 concerning Large-Scale Social Restrictions. 


\section{Shari'ah Guidance In Dealing With Pandemic/Epidemic Outbreaks}

Islam is a religion that has comprehensive teachings. His teachings do not only talk about matters of the hereafter but also cover various areas of worldly life, including in this case the problem of disease. There are many hadiths of the Messenger of Allah regarding disease including what to do when a plague strikes a country, as outlined below:

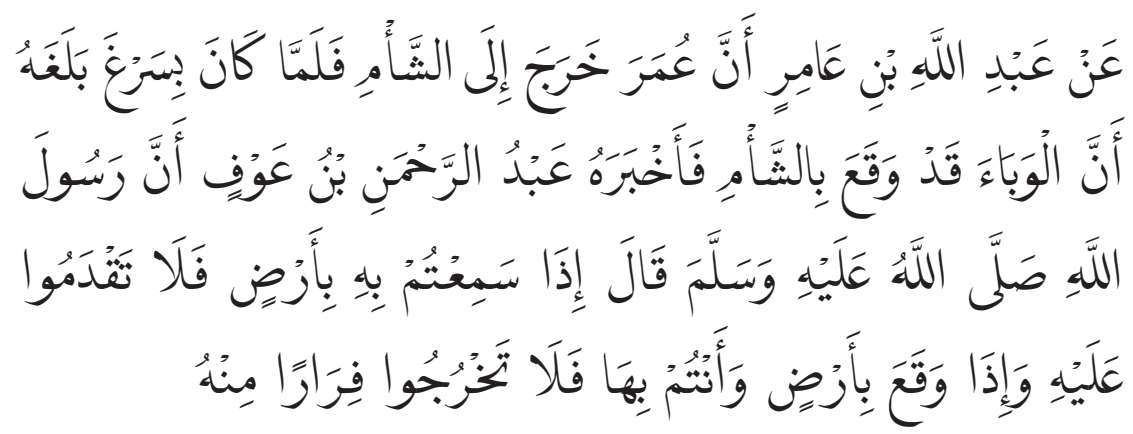

From Abdullah bin Amir that Umar once traveled to Sham. When he arrived in the area of Sargha, it was informed to him that the land of Sham was afflicted with an epidemic of infectious diseases, then Abdurrahman bin 'Auf informed him that the Messenger of Allah-peace and prayer of Allah be upon him-said: "If you hear that the plague is infecting a country, then do not go there, but if he infects a land and you are in it, then do not go out and run from it (Narrated by Imam Bukhari hadith Number 5289).

In another hadith narrated by Imam Muslim with a different chain of transmitters:

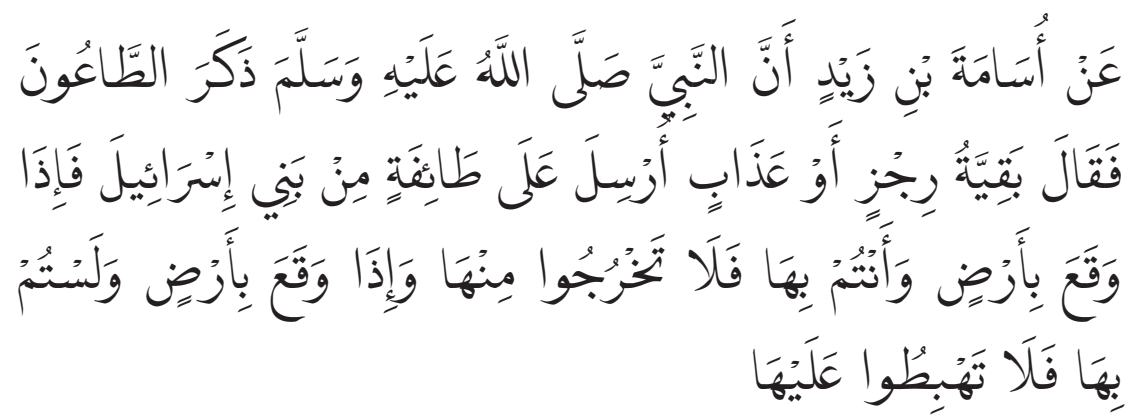

From [Osama bin Zaid] that the Prophet sallallaahu 'alaihi wasallam mentioned about tha'un (fatal diseases), he said: "(Tha'un) are the remnants of an abomination or torment that was sent to a group of 
Bani Israil. a place and there is a plague, then do not go out of it. If it occurs in an area, and you are not in it, then do not enter it." (Narrated by Imam Muslim hadith number 985)

It is also narrated by Imam Ahmad,

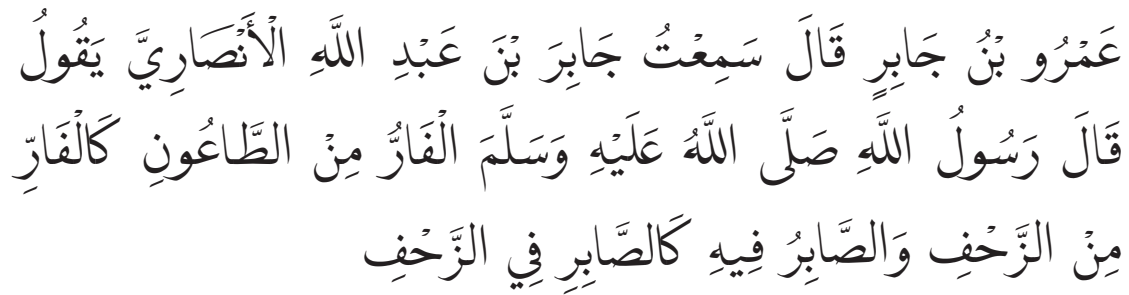

Amr bin Jabir said; I have heard [Jabir bin Abdullah Al Anshori] say; The Messenger of Allah-peace, and prayer of Allah be upon him-said: "The one who flees from the plague of Tho'un is like one who flees from war, and one who is patient in it is like one who is patient in war." (Narrated by Imam Ahmad hadith no. 13,954)

The arguments of Syara' above, explicitly prohibit people from entering or leaving the area that is being hit by an epidemic/communicable disease. Referring to the term lockdown or PSBB to limit people going in and out of an area, whether it happens by chance or not, it turns out that the lockdown method being practiced in various countries today turns out to be similar to the pattern taught by the Prophet in dealing with infectious diseases (tha'un) in the 14th century. past century. Quarantine based on the Islamic concept is not only aimed at those suspected of being infected or contaminated but also applies to those who are considered healthy. In other words, if tha' un (a dangerous and contagious disease) develops into a pandemic, then individuals who are sick or healthy, but are in a disaster area, are prohibited from leaving the house or traveling except for meeting basic needs. Eko Zulfikar, quoting Ibn Hajar al Asqalani's opinion based on a valid hadith, states that anyone who tries to avoid infectious diseases by being patient at home (stays at home) will get a reward as a martyr, even though he does not die from it. ${ }^{14}$ Even if in the end the person dies, his death will

${ }^{14}$ Eko Zulfikar, 'Tindakan Preventif Atas Penyebaran Covid-19 Dalam Perspektif Hadis', 
be classified as a martyr. In a hadith from Abu Hurairah it is said that the Apostle once said, there are 5 kinds of martyrs, namely: those who die from the plague, from stomach pain, from drowning, from falling under rubble, and martyrs in the way of Allah (Narrated by Bukhari Muslim). ${ }^{15}$ In another hadith, even death due to childbirth or due to an accident is also classified as martyrdom.

One thing that must be understood is that the status of death as syahid by some of the above causes occurs after the person concerned has complied with various shari'a provisions, including by avoiding the cause and not by picking him up. There are many stories of friends in the past who wanted to die as martyrs but failed. To die on the battlefield can be achieved easily, among others by reducing war readiness, but picking up a martyr's death with such an understanding is a mistake. Allah himself forbade his servants to fall into the valley of disaster, as confirmed in the Qur'an: also confirmed by Allah in his words

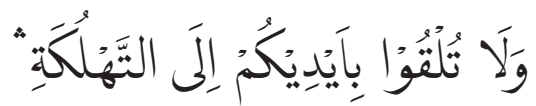

"And do not throw yourself into destruction (Al-Qur'an Surah Al Baqarah (2): 195)..$^{16}$

This means that an understanding of a proposition should not be interpreted literally (literally) and singly, but must be understood integrally and linked to the general syara' message.

\section{Synchronizing Sharia with Government Policy on PSBB}

Taklîfî law is God's provision that is imposed on people who are worthy of carrying the burden (mukallafladult) in the form of orders, prohibitions, or the freedom to choose between doing and not doing. ${ }^{17}$ Muhammad Daud Ali Ibrahim defines taklîfî law as

Diroyah: Jurnal Studi Ilmu Hadis, 5.1 (2020), 31-44 (p. 35) <https://doi.org/10.15575/diroyah. v5i1.8924>.

15 'Korban Covid-19 Bisa Dapat Pahala Syahid', Republika Online, $2020<$ https://republika. co.id/share/q7ug5f366> .

${ }^{16}$ Hasby Asshiddiqy, Al Quran Dan Terjemahnya, (Jakarta: PT. Intermasa, 1974).

${ }^{17}$ Taklifi etymologically means burden and mukallaf means bearer of the burden. This 
five kinds of rules or categories of judgment regarding objects or human behavior. Taklîfî law includes 5 kinds of law, namely; wâjib (obligatory), harâm (strongly prohibited), sunnah (recommended), makrûh (less prohibited), and mubâh (permissible). The five kinds of law are commonly called the five laws (al-Ahkâmul khamsah). ${ }^{18}$ Two of the 5 types of law above, namely harâm and makrûh, contain prohibitions to do something. In the study of taklîfî law, if a provision contains a prohibition against doing an act, then the prohibition can mean harâm (strongly forbidden) or makrûh (less forbidden). Hanafi scholars do not include the category of harâm in their classification. Instead, they divide the makrûh into 2 kinds namely, makrûh tahrîm and makrûh tanzîh. Makrûh tahrim is similar to the term harâm in the above classification, while makrûh tanzih tends to have the same meaning as the term makrûh. ${ }^{19}$

The provisions of the Sharia, whether classified as taklifi law or wadh'i law (laws that place the application of taklîfîlaw), aim to regulate human life in a vertical (with God) and horizontal relationship (with fellow creatures) for the benefit of servants both in life in the world. the world and in the hereafter. ${ }^{20}$

Concerning the government's policy in handling the Covid-19 outbreak, including the appeal not to perform collective worship (such as Friday prayers and other five daily congregational prayers), this policy must be understood from two perspectives; the first from the point of view of science and the second from the point of view of Islamic Fiqh.

According to the utilitarian theory of J. Bentham, the good or bad of an action is measured by whether the action brings happiness or not. Likewise, regarding the merits of a piece of legislation, if the

definition of taklifi law is from the author.

${ }^{18}$ Muhammad Daud Ali, Asas-Asas Hukum Islam (Jakarta: Rajawali Pers, 1991), p. 130.

${ }^{19}$ Masyfuk Zuhdi, Pengantar Hukum Syariah (Jakarta: CV Haji Masagung, 1987), p. 5.

${ }^{20}$ Dwi Runjani Juwita, 'Pemberlakuan Hukum Syariat Bagi Warga Non Muslim Di Daerah Nangroe Aceh Darussalam (Perspektif Islam Dan Ham)', El-Wasathiya: Jurnal Studi Agama, 4.1 (2016), 23-38 <http://ejournal.kopertais4.or.id/mataraman/index.php/washatiya/ article/view/2348>. 
rule brings benefit to the greater part of society, then it is said to be a good rule. ${ }^{21}$ Bentham's thinking with his utilitarian concept is not in conflict with the collective interest, because he states that what is suitable for the interests of society is what tends to add pleasure to the individuals who are members of society. This, according to him, should be the starting point in managing human life, including in arranging the law. ${ }^{22}$ In contrast to Bentham, Jhering as an adherent of this school of expediency makes the interests of the community at large that should be considered and the core of the law. ${ }^{23}$

From the point of view of Fiqh, the provisions/policies set by state officials (ulil amri), as long as they do not conflict with the Shari'a, are obligatory to be obeyed. This command of obedience is explicitly mentioned in the Qur'an which reads:

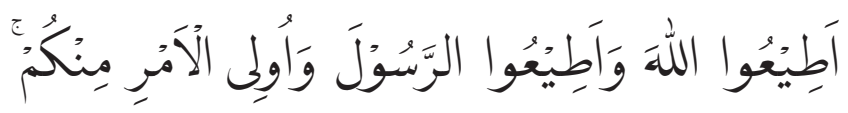

"Obey Allah and obey the Messenger and the Ulil Amri among you". (al-Quran, Surah Annisa (4): 59 )

This verse authorizes the government to make various policies to achieve the welfare and safety of the citizens. The policy must of course be in line with the will of Syara'. Obedience to the provisions of syara', or positive law that is in harmony with syara', is obligatory for the benefit of oneself and the people (public benefit).

The government, as ulîl amri, can force its people not to do certain things that can cause widespread transmission. The coercion is manifested in the form of legal provisions as well as sanctions for violators. Without sanctions, the rules will not be effective because people do not become a deterrent and have the potential to repeat their actions. The orders/ prohibitions must also be comprehensive, not only directed at a few people or certain behaviors. The regulation can touch sensitive issues,

${ }^{21}$ Lili M. Rasjidi \& Ira Thania, Dasar-Dasar Filsafat Dan Teori Hukum (Bandung: Citra Aditya Bakti, 2004), p. 64.

${ }^{22}$ Bernard.L. Tanya, et al, Teori Hukum Stratrgi Tertib Manusia Lintas Ruang Dan Waktu (Surabaya: CV. Kita., 2006), p. 74.

${ }^{23}$ Bernard.L. Tanya, et al, pp. 90-91. 
such as collective worship activities, or other religious activities, except those that are directly related to the fulfillment of urgent life needs. To determine what activities are prohibited, it becomes part of the realm of ijtihad.

Ijtihâd (legal finding) as the third source of Islamic law after the Quran and Hadith, can be utilized for the development of positive law. Even according to Mardani concerning the relationship between law and the legal system in Indonesia, religious law is an absolute element in the development of national law. Orderly community law requires the existence of appropriate regulations and sourced from religious law. ${ }^{24}$ The former Minister of Religion of the Republic of Indonesia Munawir Syadzali, quoting the opinion of Al-Izzi Ibn Abdussalam, stated that there is an open space for ijtihad for activities related to the community and all efforts should be focused on the interests of the community. ${ }^{25}$

Concerning the Government's appeal not to perform collective worship in an area affected by the epidemic, such as Friday prayers and other congregational prayers, this is acceptable in fiqh's view as long as it prevents transmission due to direct contact with sufferers (carriers). Indeed, in normal situations and conditions, the legal imposition of congregational prayers, including Friday prayers, for men is obligatory, except for 4 groups namely slaves, women, children, and the sick. ${ }^{26}$ However, in an emergency, the provisions in wadhi law in the form of mâni' (barrier) and rukhshah (dispensation) can be applied as an exception to taklîfi law. After all, basically, the application of taklîfî law on an event does not just happen but depends on whether or not the sabab (cause) and syarat (conditions) are fulfilled. It is these two provisions that make it possible to apply the principle of rukhshah to something that is harâm for emergency reasons or vice versa.

${ }^{24}$ Mardani Mardani, Hukum Islam Dalam Hukum Positif Indonesia (Jakarta: Rajawali Pers, 2018), p. 5.

${ }^{25}$ Munawir Syadzali, Ijtihad Dalam Sorotan (Bandung: Mizan, 1988), p. 122.

${ }^{26}$ Mohd. Rifai Mohd. Rifai, Ilmu Fiqih Islam Lengkap (Semarang: Toha Putra, 1978), p. 178. 
Referring to the general principles in ush $\hat{u l}$ fiqh, there are at least two qâidah (principle) that can be used, namely:

1. Hifzush shâlih, or maintaining the benefit of the people.

2. Tahammul al-darar al-khashshi li daf 'i al-dharar al-ammi. Losses of special nature can be accepted to prevent general losses from arising.

The benefit of the people is the main core of Islamic teachings. To protect the interests of the people, the loss for a small part of the community is acceptable. so that the epidemic disaster that afflicts many people in an area does not spread and cause general losses

The legal status of an act can change from haram to makrûh when the cause of the condition is suspected to have disappeared. Such a change in status departs from the ushîl fiqh principles that the nature of the emergency of something is measured by the level or level of the emergency (wa al-darûratu tuqaddaru bi qadariha). ${ }^{27}$ The level of emergency can only be determined by experts in their fields and the duty of the people is to obey what is stated by them. In this context, the role of medical experts is necessary because they are the only ones who know exactly the status or condition of something. That is why the Qur'an commands to ask the experts in their fields as the word of Allah in the Qur'an

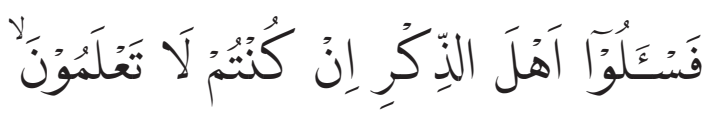

"Ask you to the experts if you do not understand/know about something. (Al-Qur'an, Surah An Nahl (16): 43).

Provisions related to lockdown are not merely the fruit of thought and performance of legal experts but after first hearing input from experts in the medical and other fields. It all boils down to the goal of saving people from the deadly Covid-19 pandemic. This medical expert understands the causes of the outbreak and the risk of transmission to both himself and others. As part of ulil amri or state affairs organizers

${ }^{27}$ See also this qaedah ushul fiqh in Masyfuk Zuhdi, p. 117. 
in certain fields, medical personnel must fight hard to find solutions on how to fight the source of the outbreak. Thus it is part of the risk that must be carried out as a person with ulil amri status. When they have done their job well and with full vigilance, but in the end, they get infected and then die, then their death is not in vain, but is rewarded by Allah as the death of the martyrs.

\section{Conclusion}

Based on the explanation above, it can be concluded that Islamic law expressly requires that a lockdown be imposed for anyone and any interest when an infectious disease occurs in an area. The prohibition to go out or enter the disaster area can have the status of harâm or makrûh depending on the level of emergency it causes based on the results of studies by experts, especially medical experts.

Government policies related to PSBB are in sync with sharia provisions; Therefore, this policy must be adhered to by all members of the community for the safety of individuals and the people.

\section{Bibliography}

Abdul Manan, Pembaruan Hukum Islam Di Indonesia. Depok: Kencana, 2017.

'Amanah dalam Menjalankan Tugas - Berita Muhammadiyah | Universitas Muhammadiyah Malang', Http://Www.Umm.Ac.Id/ <http://www. umm.ac.id/>

Arif, M. Yasin al, 'Internalization of Maqasid Al-Syari'ah in Judge's Decision' (presented at the 1st Raden Intan International Conference on Muslim Societies and Social Sciences (RIICMuSSS 2019), Atlantis Press, 2020), pp. 206-10 <https://doi.org/10.2991/ assehr.k.201113.039>

'Baru 24 Persen Warga Pakai Masker, Jubir Covid-19 Riau Ingatkan Pentingnya Disiplin Kesehatan - Riau Tanggap Virus Corona | Pemprov Riau' <https://corona.riau.go.id/2020/05/16/baru-24persen-warga-pakai-masker-jubir-covid-19-riau-ingatkan-pentingnyadisiplin-kesehatan/> 
Bernard.L. Tanya, et al, Teori Hukum Stratrgi Tertib Manusia Lintas Ruang dan Waktu. Surabaya: CV. Kita., 2006.

Asshiddiqy, Hasby. Al-Quran Dan Terjemahnya. Jakarta: PT. Intermasa, 1974.

Ira Thania, Lili M. Rasjidi. Dasar-Dasar Filsafat dan Teori Hukum. Bandung: Citra Aditya Bakti, 2004.

Juwita, Dwi Runjani, 'Pemberlakuan Hukum Syariat Bagi Warga Non Muslim di Daerah Nangroe Aceh Darussalam (Perspektif Islam dan HAM)', El-Wasathiya: Jurnal Studi Agama, 4.1 (2016), 23-38 <http://ejournal.kopertais4.or.id/mataraman/index.php/washatiya/ article/view/2348>

Khan, S., R. Siddique, A. Ali, M. Xue, and G. Nabi, 'Novel Coronavirus, Poor Quarantine, and the Risk of Pandemic', Journal of Hospital Infection, 104.4 (2020), 449-50 <https://doi.org/10.1016/j. jhin.2020.02.002>

'Korban Covid-19 Bisa Dapat Pahala Syahid', Republika Online, 2020 <https://republika.co.id/share/q7ug5f366> [accessed 22 March 2021]

Mardani, Mardani, Hukum Islam dalam Hukum Positif Indonesia. Jakarta: Rajawali Pers, 2018.

Zuhdi, Masyfuk. Pengantar Hukum Syariah. Jakarta: CV Haji Masagung, 1987.

Maulana, Iqbal, and Yuni Roslaili, 'Penerapan Syariat Islam dalam Bingkai Keberagaman Nusantara', Dusturiyah: Jurnal Hukum Islam, Perundang-undangan dan Pranata Sosial, 8.2 (2019), 96-116 <https:// doi.org/10.22373/dusturiyah.v8i2.4216>

Media, Kompas Cyber, 'Sejumlah Daerah Terapkan Lockdown, Ini Dampaknya Menurut Sosiolog', KOMPAS.com, 2020 <https://www. kompas.com/tren/read/2020/03/31/083000165/sejumlah-daerahterapkan-lockdown-ini-dampaknya-menurut-sosiolog> [accessed 22 March 2021]

___ 'U 'Update 23 Negara Berlakukan Lockdown Guna Hentikan Penyebaran Virus Corona', KOMPAS.com, $2020<$ https://www. kompas.com/tren/read/2020/03/30/161900865/update-23-negara- 
berlakukan-lockdown-guna-hentikan-penyebaran-virus-corona> Mohd. Rifai, Mohd. Rifai, Ilmu Fiqih Islam Lengkap. Semarang: Toha Putra, 1978.

Ali, Muhammad Daud. Asas-Asas Hukum Islam. Jakarta: Rajawali Pers, 1991.

Syadzali, Munawir. Ijtihad dalam Sorotan. Bandung: Mizan, 1988.

Persada, Syailendra, 'Ada ODP, PDP, Dan Lockdown, Mengenal Istilah Seputar Corona', Tempo, 2020 <https://nasional.tempo.co/ read/1320573/ada-odp-pdp-dan-lockdown-mengenal-istilah-seputarcorona>

Rakyat, Pikiran, 'Hasil Penelitian UI Kuak Adanya Keyakinan Warga Terkait Covid-19 Konspirasi Elite Global - Pikiran-Rakyat. com' <https://www.pikiran-rakyat.com/pendidikan/pr-01932654/ hasil-penelitian-ui-kuak-adanya-keyakinan-warga-terkait-covid-19konspirasi-elite-global> [accessed 22 March 2021].

Rohadi Abdulfatah, et al, Ilmu dan Tehnologi dalam Islam. Jakarta: Rineka Cipta, 1990.

Hasyimi, Sayyid Ahmad al-. Syarah Mukhtarul Ahadits. Bandung: Sinar Baru, 1993.

Syarif, Nurrohman, 'Syariat Islam dalam Perspektif Negara Hukum Berdasar Pancasila', Pandecta Research Law Journal, 11.2 (2016), 160-73 <https://doi.org/10.15294/pandecta.v11i2.7829>

Yunus, Abd Rahim, 'Posisi Negara Dalam Penegakan Syariat Islam Dalam Perspektif Sejarah', Jurnal Adabiyah, 16.2 (2016), 114-21 <https:// doi.org/10.24252/JAd.v17i116i2a2>

Yunus, Nur Rohim, 'Penerapan Syariat Islam terhadap Peraturan Daerah dalam Sistem Hukum Nasional Indonesi', HUNAFA: Jurnal Studia Islamika, 12.2 (2015), 253-79 <https://doi.org/10.24239/jsi. v12i2.394.253-279>

Zefrizal Nurdin, et al, Zefrizal nurdin, 'Hukum Islam Tentang Lockdown Dan Kesadaran Hukum Masyarakat Dalam Mentaatinya (Studi Pada Jamaah Masjid Aktif Di Kota Padang)' (Laporan Penelitian FHuk UNAND, 2020) 
Zulfikar, Eko, 'Tindakan Preventif Atas Penyebaran Covid-19 Dalam Perspektif Hadis', Diroyah: Jurnal Studi Ilmu Hadis, 5.1 (2020), 31-44 <https://doi.org/10.15575/diroyah.v5i1.8924> 